\title{
A preliminary evaluation of anticancer and antioxidant potential of two traditional medicinal plants from Lamiaceae-Pogostemon heyneanus and Plectranthus amboinicus
}

\author{
Vaishali Rai ${ }^{1}$, Vinitha Ramanath Pai $^{1 *}$, Pratapchandra Kedilaya ${ }^{2}$ \\ ${ }^{1}$ Department of Biochemistry, Yenepoya Medical College, Yenepoya University, Mangalore, Karnataka, India. \\ ${ }^{2}$ Department of Biochemistry, Srinivas Institute of Medical Sciences and Research Centre, Mangalore, Karnataka, India.
}

\begin{tabular}{|c|c|}
\hline ARTICLE INFO & ABSTRACT \\
\hline Article history: & \multirow{10}{*}{$\begin{array}{l}\text { This study investigates the cytotoxic and antioxidant potential of crude leaf extracts of Pogostemon heyneanus } \\
(P \text {. heyneanus) and Plectranthus amboinicus (P. amboinicus), medicinal plants from Lamiaceae family. Crude } \\
\text { leaf extracts, with methanol, ethanol and chloroform were evaluated for cytotoxicity in two breast cancer cell } \\
\text { lines of different grades, MCF-7 and MDA-MB-231, by MTT assay. The antioxidant activity of the extracts } \\
\text { was evaluated by DPPH and } \mathrm{H}_{2} \mathrm{O}_{2} \text { assays. The results of MTT assay revealed that chloroform extract of } P \text {. } \\
\text { heyneanus and ethanol extract of } P \text {. amboinicus were effective against MCF-7 cells. The chloroform extract of } \\
P \text {. heyneanus was more effective than } P \text {. amboinicus against MDA-MB-231. Effective antioxidant activity was } \\
\text { shown by the ethanol extract of } P \text {. amboinicus which correlated positively with the total phenol content. The } \\
\text { chloroform extract of } P \text {. heyneanus, was rich in steroids and saponins which correlated positively with the } \\
\text { cytotoxic activity. In conclusion, chloroform soluble leaf extracts of } P \text {. heyneanus, which is rich in steroids and } \\
\text { saponins shows effective cytotoxicity on both breast cancer lines studied and could be used for identification of } \\
\text { a potential anticancer principle, while ethanol extract of } P \text {. amboinicus has better potential as an antioxidant. }\end{array}$} \\
\hline Received & \\
\hline Revised on: 0 & \\
\hline Accepted on: & \\
\hline Available online: $30 / 08 / 2016$ & \\
\hline Key words: & \\
\hline Pogostemon heyneanus, & \\
\hline Plectranthus amboinicus, & \\
\hline MCF-7, MDA-MB-231, & \\
\hline Anticancer, A & \\
\hline
\end{tabular}

\section{INTRODUCTION}

Cancer is a health problem of global concern (Graidist et al., 2015). Cancer statistics project that by 2030, there will be 17 million deaths and 26 million new cases per year (Thun et al., 2009). Worldwide, breast cancer is the second leading cause of death in women (Farshori et al., 2015). Chemotherapy, the most common mode of intervention in cancer, is associated with adverse effects, from nausea to bone marrow failure. In addition, development of drug resistance is also a concern (Raguz and Yague, 2008). Therefore, the search for effective therapeutics for cancer is an ongoing process (Fadeyi et al., 2013). Alternative and complementary medicines such as Ayurveda are playing an important role in the treatment of cancer.

\footnotetext{
* Corresponding Author

Vinitha Ramanath Pai, Department of Biochemistry, Yenepoya Medical College, Yenepoya University, Mangalore, Karnataka, India 575018

Email:vinitharpai@gmail.com
}

Hence isolation of bioactive products from medicinal plants and herbs is gaining importance too (Sofi et al., 2014). Eleven percent of the basic drugs considered as essential by World Health Organization (WHO), are plant derived and modified plant products (Rates, 2000). In 1960, as part of the cancer screening program, the National Cancer Institute (NCI), U.S., screened 35,000 plant species in search of novel compounds with anticancer activity (Rubinstein and Boy, 1990). Focused researches on many promising herbs and plants have been reported (Sofi et al., 2014), as the search is ongoing. Hence, the plants, Pogostemon heyneanus (P. heyneanus) and Plectranthus amboinicus ( $P$. amboinicus), used in this study are selected based on their traditional usage and reported activities in literature (daCosta et al., 2010; Venkateshappa and Sreenath, 2013). P. heyneanus (synonym: Pogostemon patchouli Hook.) and P. amboinicus (synonym: Coleus aromaticus Benth.) are members of Lamiaceae family which have medicinal properties due to presence of aromatic oils (Venkateshappa and Sreenath, 2013). 
$P$. heyneanus is a tropical herbaceous aromatic plant, commonly called as 'patchouli'. The plant is known for its essential oil, used as a source in perfume as well as healthcare industries. Traditionally, the root decoction of the plant is used in cases of cough and asthma. The leaf poultice is used for boils, headache, jaundice, etc. (Dharmadasa et al., 2014). The plant is known to have anticancer activity and a cytotoxic compound pogopyrone B is reported from its leaves (Dharmadasa et al., 2014; Jeong et al., 2013; Peter, 2006). The second plant $P$. amboinicus has wide pharmacological activities. Although, the leaf is used to treat inflammatory disease or swelling, skin allergies, chronic cough, asthma, arthritic inflammations and malarial fever (Venkateshappa and Sreenath, 2013), the plant is also known to contain constituents responsible for cytotoxicity and antibacterial activity (daCosta et al., 2010). The present study aims to investigate the potential of crude leaf extracts using three different solvents methanol, ethanol and chloroform, of $P$. heyneanus Benth. and P. amboinicus (Lour.) Spreng for their (i) cytotoxic potential against two human breast cancer cell lines of different grades, i.e., estrogen-receptor (ER) positive MCF-7 and triple negative MDA-MB-231 and (ii) evaluate their antioxidant activity. In addition, these activities will be correlated with the phytochemical concentrations of the leaf extracts already reported by this group earlier in Rai et al., 2013.

\section{MATERIALS AND METHODS}

\section{Plant material and extraction procedure}

Leaves of two plants were collected from the uncultivated areas in Mangalore, Karnataka, India. The plants were identified and authenticated by a taxonomist at St. Agnes College, Mangalore, Karnataka, India, and the voucher specimens submitted at the herbarium. The study plants along with their family, common name and voucher numbers have been listed in Table 1.

Table 1: List of plants in the study.

\begin{tabular}{|c|c|c|c|}
\hline Name of the plant & Family & $\begin{array}{c}\begin{array}{c}\text { Common } \\
\text { name }\end{array} \\
\end{array}$ & $\begin{array}{l}\text { Voucher } \\
\text { number }\end{array}$ \\
\hline Pogostemon heyneanus & Lamiaceae & Indian & $\mathrm{SACl}$ \\
\hline Benth. & & patchouli & BOT- $15 / 102$ \\
\hline Plectranthus amboinicus & Lamiaceae & Indian & $\mathrm{SAC} /$ \\
\hline (Lour.) Spreng. & & borage & BOT- $15 / 105$ \\
\hline
\end{tabular}

Plants used in the study were authenticated by a taxonomist and voucher number assigned at the herbarium.

For the preparation of the extracts, fresh leaves of the study plants were collected, washed with distilled water, shade dried and cut into small pieces. These dried samples were powdered and stored at $4^{\circ} \mathrm{C}$ until further use. Crude extracts $(10 \%$ $\mathrm{w} / \mathrm{v})$ were made ( $24 \mathrm{~h}$, with intermittent shaking) at room temperature, using 3 solvents, i.e., methanol, ethanol and chloroform. The extracts were filtered through Whatman no. 1 and the clear filtrate was evaporated to dryness to form methanol soluble, ethanol soluble and chloroform soluble crude extracts, respectively, and stored at $4{ }^{\circ} \mathrm{C}$ until further use.

\section{Chemicals}

The chemicals used in this study include chloroform, methanol and ethanol of analytical grade from Merck. Dulbecco's modified Eagle's medium, fetal bovine serum (FBS), trypsinEDTA, trypan blue, L-glutamine, penicillin, streptomycin, amphotericin-B, dimethyl sulfoxide (DMSO), 3-(4, 5dimethylthiazol-2-yl)-2, 5-diphenyl tetrazolium (MTT), 2, 2diphenyl-1-picrylhydrazyl (DPPH), ascorbic acid, $\mathrm{H}_{2} \mathrm{O}_{2}$ and phosphate buffer saline (PBS) from Hi-media, Mumbai, India. Doxorubicin and cisplatin were from Sigma.

\section{Cell line and culture}

The anti-cancer activity was studied on two human breast cancer cell lines; MCF-7 (non-metastatic) and MDA-MB-231 (metastatic) procured from National Centre for Cell Sciences, Pune, India. The cells were cultured in Dulbecco's modified eagle medium (DMEM) supplemented with, 10\% heat inactivated FBS, $2 \mathrm{mM}$ L-glutamine, penicillin (100 IU/ml), streptomycin (100 $\mu \mathrm{g} / \mathrm{ml})$ and amphotericin-B $(5 \mu \mathrm{g} / \mathrm{ml})$ in humidified atmosphere of $5 \% \mathrm{CO}_{2}$ at $37^{\circ} \mathrm{C}$ until confluent. The cells were trypsinized with Trypsin-EDTA solution. The stock cultures were grown in $25 \mathrm{~cm}^{2}$ flat bottles and the cell viability studies were carried out in 96 well microtitre plates.

\section{Treatment for MCF-7 and MDA-MB-231 cells}

Cells were plated in 96 well flat bottom microtitre plates at a density of $5 \times 10^{4}$ cells per well for MTT assay and were cultured at $37^{\circ} \mathrm{C}$, in $5 \% \mathrm{CO}_{2}$ atmosphere, for $24 \mathrm{~h}$, to allow cell adhesion. After $24 \mathrm{~h}$, when partial monolayers were formed, medium was removed and cells were treated with different concentrations of either the standard drug (Doxorubicin/Cisplatin) $(0.5 \mu \mathrm{g} / \mathrm{ml}, 1.5 \mu \mathrm{g} / \mathrm{ml}, 5 \mu \mathrm{g} / \mathrm{ml}$ and $10 \mu \mathrm{g} / \mathrm{ml})$ or the crude leaf extracts $(31.25 \mu \mathrm{g} / \mathrm{ml}, 62.5 \mu \mathrm{g} / \mathrm{ml}, 125 \mu \mathrm{g} / \mathrm{ml}, 250 \mu \mathrm{g} / \mathrm{ml}$ and 500 $\mu \mathrm{g} / \mathrm{ml})$ for $48 \mathrm{~h}$.

\section{In vitro cytotoxicity by MTT assay}

The assay was performed as per the procedure described previously (Denizot and Lang, 1986; Mossman, 1983). MTT is a colorimetric assay. In this assay, 3-(4, 5-dimethythiazol- 2-yl)-2, 5-diphenyl tetrazolium bromide (MTT) which is yellow in colour is reduced by mitochondrial succinate dehydrogenase to an insoluble, coloured formazan product which is dark purple in colour. The cells are then treated with an organic solvent (such as DMSO, isopropoanol, etc.) which solubilizes the cells and the formazan is released, which is measured spectrophotometrically $(570 \mathrm{~nm})$. Since reduction of MTT can only occur in metabolically active cells the level of activity is a measure of the viable cells.

After the treatment, the solutions in the wells were discarded and $100 \mu \mathrm{l}$ of freshly prepared MTT ( $1 \mathrm{mg} / \mathrm{ml}$ PBS) was added to each well. The plates were shaken gently and incubated at $37^{\circ} \mathrm{C}$ in $5 \% \mathrm{CO}_{2}$ atmosphere for $4 \mathrm{~h}$. After $4 \mathrm{~h}$, the supernatant was removed and the formazan crystals formed in the cells were solubilized by addition of $100 \mu \mathrm{l}$ of DMSO. The absorbance was 
read using a micro-plate reader (Bio-Tek, ELX-800 MS) at 570 $\mathrm{nm}$. The assay was done in triplicate for each of the extract.

The percentage growth inhibition was calculated using the formula below:

$\%$ Growth inhibition $=\frac{(\text { Control absorbance }- \text { test absorbance }) \times 100}{\text { (Control absorbance })}$

A graph was plotted with concentration of standard drug/extract on $\mathrm{x}$-axis and absorbance on $\mathrm{y}$-axis. The $\mathrm{IC}_{50}$ (concentration of drug required to kill $50 \%$ of cells in exponentially growing cultures after a $48 \mathrm{~h}$ exposure to the drug) values were calculated from the curve. The most effective extract was used for further studies with MDA-MB-231 cell line.

\section{Antioxidant activity by DPPH radical scavenging assay}

Free radical scavenging activity of the crude leaf extracts was measured using DPPH radical scavenging assay (Gupta et al., 2007). Crude extracts (10 to $100 \mu \mathrm{g} / \mathrm{ml}$ ) solutions were mixed with $2 \mathrm{ml}$ of freshly prepared DPPH solution. Ascorbic acid (10 to 100 $\mu \mathrm{g} / \mathrm{ml}$ ) was used as positive control. Reaction mixture was incubated in the dark for $15 \mathrm{~min}$ and optical density read at 523 nm against a blank. The capability of scavenging DPPH radicals were calculated using the following equation:

$\%$ DPPH scavenged $=\frac{(\text { Control absorbance }- \text { test absorbance }) \times 100}{(\text { Control absorbance })}$

\section{$\mathrm{H}_{2} \mathrm{O}_{2}$ scavenging assay}

$\mathrm{H}_{2} \mathrm{O}_{2}$ scavenging activity of the crude leaf extracts was measured according to the previous method by Ruch et al., 1989. Crude extracts ( 25 to $250 \mu \mathrm{g} / \mathrm{ml}$ ) solutions were added to $0.6 \mathrm{ml}$ $\mathrm{H}_{2} \mathrm{O}_{2}(40 \mathrm{mM})$ solution and the absorbance of the solution was read at $230 \mathrm{~nm}$ after $10 \mathrm{~min}$ against blank containing phosphate buffer without $\mathrm{H}_{2} \mathrm{O}_{2}$. Phosphate buffer with $\mathrm{H}_{2} \mathrm{O}_{2}$ served as control. Ascorbic acid (25 to $250 \mu \mathrm{g} / \mathrm{ml}$ ) was used as a positive control. The $\% \mathrm{H}_{2} \mathrm{O}_{2}$ radical scavenged was calculated using the formula:

$\% \mathrm{H} 2 \mathrm{O} 2$ scavenged $=\frac{(\text { Control absorbance }- \text { test absorbance }) \times 100}{\text { (Control absorbance })}$

\section{Statistical Analysis}

Results were expressed as mean \pm standard deviation values of triplicate experiments $(n=3)$. Analysis was done using one-way analysis of variance followed by LSD posthoc test for comparison between control and treatment groups with SPSS version 14 software (IBM). Pearson's correlation coefficient test was applied to find association between anticancer, antioxidant activities with total phenolic content and concentration of steroids. $\mathrm{P}<0.05$ was considered to be statistically significant.

\section{RESULTS AND DISCUSSION}

In this preliminary investigation, it is evident that the crude extracts from the leaves of $P$. heyneanus and $P$. amboinicus have appreciable anticancer activity against breast cancer cell lines and $P$. amboinicus has good antioxidant potential also.

\section{MTT assay for cytotoxicity of the extracts with MCF-7 cells}

The cytotoxic activity of $P$. heyneanus methanol (PHM), ethanol (PHE), chloroform (PHC) soluble extracts and $P$. amboinicus methanol (PAM), ethanol (PAE), chloroform (PAC) soluble extracts on MCF-7 cells were evaluated by MTT assay. The PHM, PHE and PHC extracts gave $\mathrm{IC}_{50}$ values of 102.33 $\mu \mathrm{g} / \mathrm{ml}, 262.33 \mu \mathrm{g} / \mathrm{ml}$ and $56.66 \mu \mathrm{g} / \mathrm{ml}$ respectively. The PAM, PAE and PAC extracts gave $\mathrm{IC}_{50}$ values of $100.33 \mu \mathrm{g} / \mathrm{ml}, 60 \mu \mathrm{g} / \mathrm{ml}$ and $167 \mu \mathrm{g} / \mathrm{ml}$ respectively. PHC ( $\mathrm{IC}_{50}$ value: $56.66 \pm 0.88 \mu \mathrm{g} / \mathrm{ml}$ ) and PAE ( $\mathrm{IC}_{50}$ value: $60 \pm 1.15 \mu \mathrm{g} / \mathrm{ml}$ ) have shown effective cytotoxicity, ( $\mathrm{p}<0.001$ ) (Table 2 ). The $\mathrm{IC}_{50}$ value of Doxorubicin (positive control) was $1.09 \pm 0.03 \mu \mathrm{g} / \mathrm{ml}$. The two crude extracts with significant cytotoxicity against $\mathrm{MCF}-7$ cell lines, i.e., PHC and PAE were further tested for their efficacy in MDA-MB-231 cell lines.

Table 2: Effect of crude extracts/positive control against MCF-7 cell line by MTT assay.

\begin{tabular}{|c|c|c|c|}
\hline \multirow{2}{*}{ Name of the Plant } & \multicolumn{3}{|c|}{ IC $_{50}$ value $(\mu \mathrm{g} / \mathrm{ml})$} \\
\hline & Methanol (M) & Ethanol (E) & Chloroform (C) \\
\hline$(\mathrm{PH})$ & .76 & 262 & $38 *$ \\
\hline & & & \\
\hline $\begin{array}{l}\text { Doxorubicin } \\
\text { (positive control) }\end{array}$ & & & \\
\hline \multicolumn{4}{|c|}{$\begin{array}{l}\text { Methanol, ethanol and chloroform soluble crude extracts of the study plants } \\
\text { were screened against MCF-7 cell line at } 5 \text { different concentrations }(500 \mu \mathrm{g} / \mathrm{ml} \text {, } \\
250 \mu \mathrm{g} / \mathrm{ml}, 125 \mu \mathrm{g} / \mathrm{ml}, 62.5 \mu \mathrm{g} / \mathrm{ml} \text { and } 31.25 \mu \mathrm{g} / \mathrm{ml} \text { ) and the } \% \text { cell death was } \\
\text { calculated. Graphs were plotted and } \mathrm{IC}_{50} \text { values (concentration at which } 50 \% \\
\text { cell death was observed) were determined and expressed as } \mu \mathrm{g} / \mathrm{ml} \text {. } * \mathrm{P}<0.05 \\
\text { (one way ANOVA followed by LSD post hoc analysis). }\end{array}$} \\
\hline
\end{tabular}

\section{MTT assay of PHC and PAE with MDA-MB-231 cell lines}

Cytotoxic activity of PHC and PAE extracts on MDAMB-231 cell lines gave $\mathrm{IC}_{50}$ values of $152 \pm 0.75 \mu \mathrm{g} / \mathrm{ml}$ and 246.8 $\pm 0.86 \mu \mathrm{g} / \mathrm{ml}$, respectively. The $\mathrm{IC}_{50}$ value of Cisplatin (positive control) was $0.5 \pm 0.13 \mu \mathrm{g} / \mathrm{ml}$. Comparison of the $\mathrm{IC}_{50}$ values of the crude leaf extracts (PHC and PAE) on MCF-7 and MDA-MB231 cells show that there is significant difference $(\mathrm{p}<0.01)$ in their cytotoxic effects on the two cell lines tested (Table 3 ).

Table 3: Comparison of IC50 values of crude extracts in MCF-7 and MDAMB-231 breast carcinoma cell line

\begin{tabular}{ccc}
\hline Name of the extract & \multicolumn{2}{c}{ IC $_{\mathbf{5 0}}$ value $(\boldsymbol{\mu g} / \mathbf{m l})$} \\
\hline MCF-7 & MDA-MB-231 \\
\hline PAE & $56.66 \pm 0.88^{*}$ & $152.00 \pm 0.75$ \\
The $\mathrm{IC}_{50}$ values of the extracts against MCF-7 and & MDA-MB-231 breast
\end{tabular}

The $\mathrm{IC}_{50}$ values of the extracts against MCF-7 and MDA-MB-231 breast carcinoma cell lines were estimated from the graphs plotted with concentration of extracts $(\mu \mathrm{g} / \mathrm{ml})$ on the $\mathrm{X}$ axis and cell death (\%) observed on the $\mathrm{Y}$ axis and expressed as $\mu \mathrm{g} / \mathrm{ml}$. *P $<0.05$ (one way ANOVA followed by LSD post hoc analysis). Abbreviations: Extracts of $P$. heyneanus in chloroform - PHC; $P$. amboinicus in ethanol - PAE.

Rai et al., (2013) have reported that the composition of phytochemicals in an extract varies with the solvents used for their extraction. As a result, the biological activities exhibited by the extracts also vary. Variations in the sensitivity of different cell 
lines from the same tissue origin, to the cytotoxic effects of plant extracts and drugs is also a known fact. For example, the effect of genistein on different types of breast cancer cell lines has shown that the growth arresting action of genistein varies from one cell line to another (Dampier et al., 2001).

In the present study we have used human breast cancer cell lines, i.e., ER positive MCF-7 and triple negative MDA-MB-231 to test the cytotoxicity of the crude leaf extracts of $P$. heyneanus and $P$. amboinicus. These two cell lines are of breast tissue but with different characteristics. The chloroform extract of $P$. heyneanus, had least $\mathrm{IC}_{50}$ value against $\mathrm{MCF}-7$ cell line $\left(\mathrm{IC}_{50}\right.$ value: $56.66 \pm 0.88 \mu \mathrm{g} / \mathrm{ml}$ ). Jeong et al., (2013) have reported the cytotoxic potential of the same plant in MCF-7 cells, but with hydrodistilled extracts. They have identified that patchouli alcohol is responsible for the decreased proliferation and apoptosis.

Among the extracts of $P$. amboinicus, the most effective was ethanol soluble crude extract (PAE) $\left(\mathrm{IC}_{50}: 60 \pm 1.15 \mu \mathrm{g} / \mathrm{ml}\right)$. This value is comparable to an earlier report by Thirugnanasampandan et al., (2015) which was also studied in MCF-7 cell line. However, unlike the crude extract used in this study, the reported $\mathrm{IC}_{50}: 53 \pm 0.01 \mu \mathrm{g} / \mathrm{ml}$ was of a purified essential oil from the leaf of $P$. amboinicus. The cytotoxic effect has been related to the presence of carvacrol, a phenolic compound. Presence of phenols in PAE has already been reported earlier in the preliminary phytochemical screening studies (Pellati et al., 2013; Rai et al., 2013). Yet another study has reported the $\mathrm{IC}_{50}$ value of the crude extract from this plant to be $1382.8 \mu \mathrm{g} / \mathrm{ml}$, in the same cell line (Hasibuan et al., 2013). This clearly shows that the crude extract of this study has a greater potential as a source for an anticancer principle.

Further, MCF-7 showed greater sensitivity to PHC and PAE than MDA-MB-231 (Table 3). MCF-7 is from a p53 wild type, ER positive, luminal type low grade tumor with downregulated caspase 3, whereas MDA-MB-231 is from a p53 mutant, triple receptor negative and is a high grade, basal type tumor with normal expression of caspase 3 (Graidist et al., 2015). Caspase 3 and estrogen receptors are factors which either independently or in combination with other factors determine the sensitivity of the cells to extracts or drugs. Differential responses in the two breast cancer cell lines could be related to the presence of estrogen receptor (in MCF-7) or presence of caspase 3 (as in MDA-MB-231) (Finn et al., 2009; Reddel et al., 1985; Yang et al., 2007). Caspase 3 activation leads to apoptosis in MDA-MB-231 cells (Arunasree, 2010) and presence of ER positive receptor in MCF-7 makes the cell line more susceptible to decreased proliferation and cell cycle arrest (Finn et al., 2009; Reddel et al., 1985).

This probably explains the difference in the sensitivity of the two cell lines to the extracts of this study. Despite the differences in the characteristics of the cell lines, there is appreciable cell death in the caspase deficient, ER positive MCF-7 as well as ER negative MDA-MB-231 cells on treatment of the
PHC and PAE, hinting at the efficacy of the extracts for isolation of anticancer principle.

\section{Free radical scavenging activity \\ DPPH radical scavenging assay}

DPPH radical scavenging activity of PHM, PHE, PHC,

PAM, PAE and PAC extracts with ascorbic acid as positive control were evaluated based on their ability to quench DPPH and $\mathrm{H}_{2} \mathrm{O}_{2}$ radicals. $50 \%$ of the DPPH free radicals were scavenged at $25 \pm 1.2 \mu \mathrm{g} / \mathrm{ml}\left(\mathrm{IC}_{50}\right.$ value) by ascorbic acid, a positive control. However, the crude extracts exhibited DPPH radical scavenging activity in decreasing order as follows: PAE ( $\mathrm{IC}_{50}$ : $59.5 \pm 2.9$ $\mu \mathrm{g} / \mathrm{ml})>$ PHM $\left(\mathrm{IC}_{50}: 85 \pm 2.35 \mu \mathrm{g} / \mathrm{ml}\right)>$ PHE $\left(\mathrm{IC}_{50}: 96.4 \pm 1.6\right.$ $\mu \mathrm{g} / \mathrm{ml})>$ PHC $\left(\mathrm{IC}_{50}: 99.2 \pm 0.6 \mu \mathrm{g} / \mathrm{ml}\right)>$ PAM $\left(\mathrm{IC}_{50}: 124.9 \pm 1.8\right.$ $\mu \mathrm{g} / \mathrm{ml})>$ PAC $\left(\mathrm{IC}_{50}: 137.1 \pm 0.7 \mu \mathrm{g} / \mathrm{ml}\right)$ (Fig. 1).

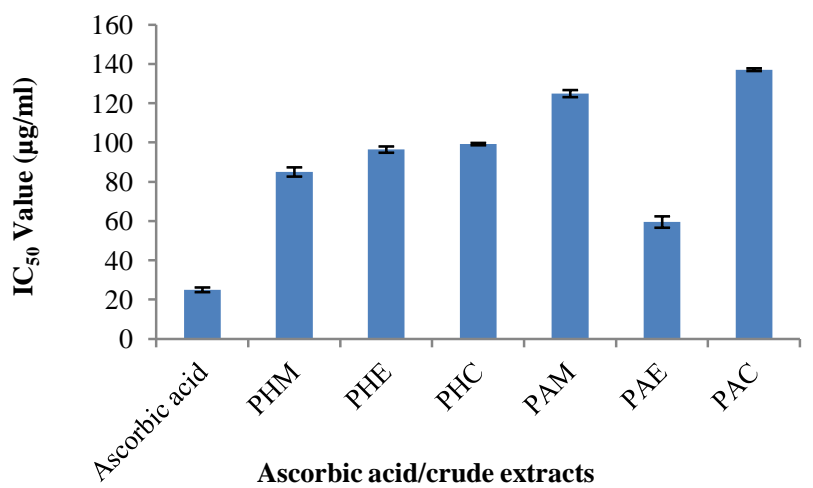

Fig. 1: Free radical scavenging activity of methanol, ethanol and chloroform soluble crude leaf extracts of $P$. heyneanus and $P$. amboinicus by DPPH radical scavenging method. Crude extracts were tested for DPPH radical scavenging activity ranging from $10 \mu \mathrm{g} / \mathrm{ml}$ to $100 \mu \mathrm{g} / \mathrm{ml}$ and $\%$ inhibition was calculated. Ascorbic acid was used as positive control. Abbreviations: Extracts of $P$. heyneanus in methanol - PHM, P. heyneanus in ethanol - PHE, P. heyneanus in chloroform - PHC; P. amboinicus in methanol - PAM, P. amboinicus in ethanol - PAE, P. amboinicus in chloroform - PAC.

\section{$\mathrm{H}_{2} \mathrm{O}_{2}$ scavenging assay}

Ascorbic acid (positive control) scavenged $50 \%$ of the $\mathrm{H}_{2} \mathrm{O}_{2}$ radicals at $155 \pm 2.3 \mu \mathrm{g} / \mathrm{ml}$ ( $\mathrm{IC}_{50}$ value). The crude extracts exhibited $\mathrm{H}_{2} \mathrm{O}_{2}$ scavenging activity in decreasing order as follows: $\operatorname{PAE}\left(\mathrm{IC}_{50}: 163.8 \pm 0.5 \mu \mathrm{g} / \mathrm{ml}\right)>\mathrm{PHC}\left(\mathrm{IC}_{50}: 238.6 \pm 0.4 \mu \mathrm{g} / \mathrm{ml}\right)>$ PHM $\left(\mathrm{IC}_{50}: 284.9 \pm 1.5 \mu \mathrm{g} / \mathrm{ml}\right)>\operatorname{PHE}\left(\mathrm{IC}_{50}: 462.3 \pm 0.7 \mu \mathrm{g} / \mathrm{ml}\right)>$ PAM $\left(\mathrm{IC}_{50}: 633.5 \pm 0.9 \mu \mathrm{g} / \mathrm{ml}\right)>\operatorname{PAC}\left(\mathrm{IC}_{50}: 1830.4 \pm 0.5 \mu \mathrm{g} / \mathrm{ml}\right)$ (Fig. 2).

The ethanol extract of $P$. amboinicus (PAE) was able to scavenge both DPPH and $\mathrm{H}_{2} \mathrm{O}_{2}$ radicals effectively with $\mathrm{IC}_{50}$ values close to that of ascorbic acid (positive control). Studies by Hasibuan et al., 2013; Bhattacharjee et al., 2011, have reported the antioxidant activity of $P$. amboinicus by DPPH radical scavenging assay in terms of $\mathrm{IC}_{50}$ value to be $281.26 \mu \mathrm{g} / \mathrm{ml}$ and $207.57 \mu \mathrm{g} / \mathrm{ml}$ respectively and $\mathrm{H}_{2} \mathrm{O}_{2}$ scavenging activity to be $1059.88 \mu \mathrm{g} / \mathrm{ml}$. The extract of this study is $4.7,3.5$ and 6.5 fold more effective, respectively, than the values reported by Hasibuan et al., 2013 and Bhattacharjee et al., 2011. The antioxidant potential of the extracts 
could be attributed to the presence of phenols and flavonoids which are reported to be present in P. amboinicus (Rai et al., 2013; Rout et al., 2012).

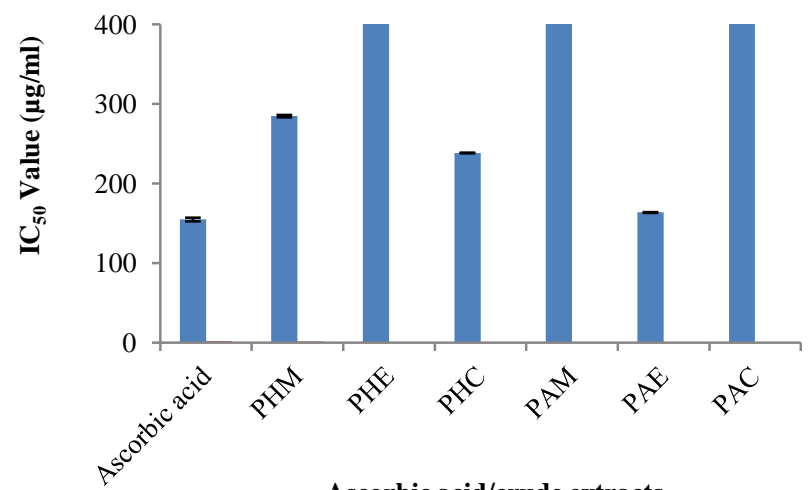

Fig. 2: $\mathrm{H}_{2} \mathrm{O}_{2}$ scavenging activity of $P$. heyneanus and $P$. amboinicus crude leaf extracts. Ascorbic acid was used as the positive control. Abbreviations: Extracts of $P$. heyneanus in methanol - PHM, P. heyneanus in ethanol - PHE, P. heyneanus in chloroform - PHC; $P$. amboinicus in methanol - PAM, P. amboinicus in ethanol - PAE, P. amboinicus in chloroform - PAC

The earlier report from this group on the qualitative analysis of the chloroform extract of $P$. heyneanus had only steroids and flavonoids. The quantitative analysis revealed high concentration of steroids (73.40 $\pm 0.29 \% \mathrm{w} / \mathrm{w})$, followed by, flavonoids $(3.20 \pm 0.02 \% \mathrm{w} / \mathrm{w})$, tannins $(1.17 \pm 0.02 \% \mathrm{w} / \mathrm{w})$ and total phenols $(0.66 \% \mathrm{w} / \mathrm{w})$ (Rai et al., 2013). The leaf powder of $P$. heyneanus had high concentrations of saponins $(14.23 \pm 0.21$ gms\%). Saponins are known to have cytotoxic effects, which explains the effective cell death on treatment of chloroform extracts of this plant (Podolak et al., 2010). Anticancer activity of this extract showed positive correlation with the steroid concentration $(r=0.85 ; p<0.05)$ and a negative correlation with the total phenolic content $(r=-0.4)$ and weak correlation with the antioxidant activity $(\mathrm{r}=0.2 ; \mathrm{p}>0.05)$, that was not of statistical significance. However, PAE extracts were rich in total phenols $(15.13 \pm 0.36 \% \mathrm{w} / \mathrm{w})$, followed by tannins $(3.56 \% \mathrm{w} / \mathrm{w})$ and flavonoids $(2.53 \% \mathrm{w} / \mathrm{w})$. There was a strong positive correlation ( $\mathrm{r}$ $=0.9, \mathrm{p}<0.05)$ between total phenolic content and antioxidant activity suggesting the antioxidant activity may be due to the total phenols as shown earlier by Gupta et al., (2007). Although this extract exhibits anticancer activity, it does not correlate significantly with the total phenol content $(\mathrm{p}>0.05)$. However, the anticancer activity may be due to presence of saponins and tannins. From this preliminary evaluation, it is evident that these crude extracts can be used for isolation, purification and identification of the phytochemicals responsible for these activities. This maybe the next step in the scientific evaluation of anticancer and antioxidant activities of these plants.

\section{CONCLUSION}

In conclusion, the chloroform extract of $P$. heyneanus and ethanol extract of $P$. amboinicus have good anticancer potential. Human breast cancer cell lines of different grades MCF-
7 and MDA-MB-231 show slight differences in their sensitivities to the extracts. The concentration of steroids and saponins is higher in the chloroform extract of $P$. heyneanus and the concentration of phenols is higher in the ethanol extract of $P$. amboinicus. Hence chloroform extract of $P$. heyneanus could be good source for anticancer principle and ethanol extract of $P$. amboinicus could be one for an antioxidant.

\section{ACKNOWLEDGEMENTS}

This study was supported by Junior Research Fellowship Programme, Yenepoya University, Mangalore, Karnataka, India. We would also like to acknowledge Yenepoya Research Centre, Yenepoya University for the cell culture facility. We acknowledge Dr. Noeline J. Pinto, taxonomist at St Agnes College, Mangalore, Karnataka, India for the identification of study plants.

\section{REFERENCES}

Arunasree KM. Anti-proliferative effects of carvacrol on a human metastatic breast cancer cell line, MDA-MB 231. Phytomedicine, 2010; 17:581-588.

Bhattacharjee P, Hullatti KK, Vijay KM. Antihelmintic and antioxidant activity of alcoholic extracts of different parts of Coleus amboinicus Lour. International Journal of Research in Ayurveda and Pharmacy, 2011; 1:181-185.

daCosta JGM, Campos AR, Brito SA, Pereira CKB, Souza EO, Rodrigues FFG. Biological screening of araripe basin medicinal plants using Artemia salina Leach and pathogenic bacteria. Pharmacognosy Magazine, 2010; 6:331-334.

Dampier K, Hudson EA, Howells LM, Manson MM, Walker RA, Gescher A. Differences between human breast cell lines in susceptibility towards growth inhibition by genistein. British Journal of Cancer, 2001; 85:618-624.

Denizot F, Lang R. Rapid colorimetric assay for cell growth and survival: modifications to the tetrazolium dye procedure giving improved sensitivity and reliability. Journal of Immunological Methods, 1986; 89:271-277.

Dharmadasa RM, Rathnayake RMDH, Abeysinghe DC, Rashani SAN, Samarasinghe K, Attanayake ALM. Screening of local and introduced varieties of Pogostemon heyneanus Benth. (Lamiaceae), for superior quality physical, chemical and biological parameters. World Journal of Agricultural Research, 2014; 2:261-266.

Fadeyi SA, Fadeyi OO, Adejumo AA, Okoro C, Myles EL. In vitro anticancer screening of 24 locally used Nigerian medicinal plants. BMC Complementary and Alternative Medicine, 2013; 13:79-87.

Farshori NN, Al-Sheddi ES, Al-Oqail MM, Musarra J, AlKhedhairy AA, Siddiqui MA. Anticancer activity of Petroselinum sativum seed extracts on MCF-7 human breast cancer cells. Asian Pacific Journal of Cancer Prevention, 2013; 14:5719-5723.

Finn RS, Dering J, Conklin D, Kalous O, Cohen DJ, Desai AJ, Ginther C, Atefi M, Chen I, Fowst C, Los G. PD 0332991, a selective cyclin D kinase 4/6 inhibitor, preferentially inhibits proliferation of luminal estrogen receptor-positive human breast cancer cell lines in vitro. Breast Cancer Research, 2009; 11(5):R77.

Graidist P, Martla M, SukpondmaY. Cytotoxic activity of Piper cubeba extract in breast cancer cell lines. Nutrients, 2015; 7:2707-2718.

Gupta MK, Lagarkha R, Sharma PK. Antioxidant activity of the successive extracts of Grewia asiatica leaves. Asian Journal of Chemistry, 2007; 19:3417-3420.

Hasibuan PA, Rosidah IS, Nasution MP. Antioxidant and cytotoxic activities of Plectranthus amboinicus (Lour.) Spreng. extracts. 
International Journal of Pharmacy Teaching and Pharmacy Practices, 2013; 4:755-758.

Jeong JB, Choi J, Lou Z, Jiang X, Lee SH. Patchouli alcohol, an essential oil of Pogostemon cablin, exhibits anti-tumorigenic activity in human colorectal cancer cells. International Immunopharmacology, 2013; 16:184-190.

Maiti S, Geetha KA. 2006. Herbs, spices and cancer. In: Peter KV.ed. Handbook of herbs and spices. Cambridge: Woodhead publishing limited 138-149.

Mossman T. Rapid colorimetric assay for cell growth and survival: application to proliferation and cytotoxicity assay. Journal of Immunological Methods, 1983; 65:55-63.

Pellati F, Bruni R, Righi D, Grandini A, Tognolini M, Prencipe FP, Poli F, Benvenuti S, Rio DD, Rossi D. Metabolite profiling of polyphenols in a Terminalia chebula Retzius ayurvedic decoction and evaluation of its chemopreventive activity. Journal of Ethnopharmacology, 2013; 147:277-285.

Podolak I, Galanty A, Sobolewska D. Saponins as cytotoxic agents: a review. Phytochemistry Reviews, 2010; 9:425-474.

Raguz S, Yague E. Resistance to chemotherapy: New treatments and novel insights into an old problem. British Journal of Cancer, 2008; 99:387-391.

Rai VM, Pai VR, Kedilaya HP, Hegde S. Preliminary phytochemical screening of members of Lamiaceae family: Leucas linifolia, Coleus aromaticus and Pogostemon patchouli. International Journal of Pharmaceutical Sciences Review and Research, 2013; 21:131137.

Rates SMK. Plants as source of drugs. Toxicon, 2001; 39:603613.

Reddel RR, Murphy LC, Hall RE, Sutherland RL. Differential sensitivity of human breast cancer cell lines to the growth-inhibitory effects of tamoxifen. Cancer Research, 1985; 45:1525-1531.

Rout OP, Acharya R, Mishra SK, Sahoo R. Pathorchur (Coleus aromaticus): a review of the medicinal evidence for its phytochemistry and pharmacology properties. International Journal of Applied Biology and Pharmaceutical Technology, 2012; 3:348-355.
Rubinstein LV, Boy MR. Comparison of in vitro anticancer-drug-screening data generated with a tetrazolium assay versus a protein assay against a diverse panel human tumor cell lines. Journal of National Cancer Institute, 1990; 82:1113-1118.

Ruch RJ, Cheng SJ, Klainig JE. Prevention of cytotoxicity and inhibition of intracellular communication by antioxidant catechins isolated from Chinese green tea. Carcinogen, 1989; 10:1003-1008.

Sofi MS, Sateesh MK, Bashir M. Screening of the ethnobotanicals against MDA-MB-231 and MCF-7 breast cancer cell lines. International Journal of Phytopharmacy, 2014; 4:140-147.

Thirugnanasampandan R, Ramya G, Gogulramnath M, Jayakumar R, Kanthimathi MS. Evaluation of cytotoxic, DNA protecting and LPS induced MMP-9 down regulation activities of Plectranthus amboinicus (Lour.) Spreng. essential oil. Pharmacognosy Journal, 2016; 7:32-36.

Thun MJ, DeLancey JO, Center MM, Jemal A, Ward EM. The global burden of cancer: priorities for prevention. Carcinogenesis, 2009; $31: 100-110$

Venkateshappa SM, Sreenath KP. Potential Medicinal Plants of Lamiaceae. American International Journal of Research in Formal, Applied \& Natural Sciences, 2013; 3:82-87.

Yang S, Zhou U, Yang X. Caspase-3 status is a determinant of the differential responses to genistein between MDA-MB-231 and MCF-7 breast cancer cells. Biochimica et Biophysica Acta, 2007; 903-911.

\section{How to cite this article:}

Vaishali Rai, Vinitha Ramanath Pai, Pratapchandra Kedilaya. A preliminary evaluation of anticancer and antioxidant potential of two traditional medicinal plants from Lamiaceae - Pogostemon heyneanus and Plectranthus amboinicus. J App Pharm Sci, 2016; 6 (08): 073-078. 